Original Article

\title{
THE PATENTED DRUGS UTILIZATION: A STUDY AT NGUYEN DINH CHIEU HOSPITAL IN BEN TRE PROVINCE FROM 2011 TO 2017
}

\author{
CU THANH-TUYENa, TRAN-THI NGOC-VAN", DANG KIM-LOANc, HOANG-THY NHAC-VUa*
}

aUniversity of Medicine and Pharmacy at Ho Chi Minh City, Vietnam, bMedical College of Quang Nam, Vietnam, cNguyen Dinh Chieu Hospital, Ben Tre Province, Vietnam

Email: hoangthynhacvu@upm.edu.vn

Received: 17 Nov 2018 Revised and Accepted: 29 Mar 2019

\section{ABSTRACT}

Objective: With their new and efficacious active ingredients, patented drugs have important roles in offering high-quality healthcare. However, huge cost-related barriers in accessing patented drugs along with the availability of low-cost bioequivalent generics have great impact on drugs policy in Vietnam. To understand situation of patented drugs utilization at hospitals for a certain period, this pilot study was conducted at NguyenDinh-Chieu Hospital in Ben-Tre Province.

Methods: The cross-sectional descriptive study was conducted on the retrospective data of all patented drugs used at Nguyen-Dinh-Chieu Hospital in Ben-Tre Province from 2011-2017. Characteristics of drugs utilization were described by frequency and percentage of drugs quantities and costs. Criteria for the description were as follows: active ingredient, route of administration, therapeutic class and manufacturing country. Data were extracted from the hospital information system and were processed by R software.

Results: From 2011 to 2017, there were 212 patented drugs used which related to 145 active ingredients and 20 therapeutic classes. 88\% were single active ingredient drugs and $49 \%$ were oral drugs. Antimicrobial and cardiovascular drugs represented the largest number of drugs and the highest cost. $79 \%$ of patented drugs were manufactured by companies in Europe and the majority came from France and Germany.

Conclusion: This study provided initial information about the utilization of patented drugs during a long period of time at a Vietnamese hospital. The understanding gained will aid medical managers in assessment and adjustment of the drugs list, thus, optimizing the hospital budget and the equity in access to drugs within communities.

Keywords: Patented drugs, Drugs utilization, Drugs list

(C) 2019 The Authors. Published by Innovare Academic Sciences Pvt Ltd. This is an open access article under the CC BY license (http://creativecommons.org/licenses/by/4.0/) DOI: http://dx.doi.org/10.22159/ijpps.2019v11i5.30841

\section{INTRODUCTION}

Drug utilization research is crucial to ensure an accurate supply of appropriate drugs at hospitals [1-2]. Of particular concern in this field is studying the utilization of patented drugs in healthcare and treatment practices. Although patented drugs offer new and efficacious active ingredients, purchasing and using them in hospitals presents some challenges. In Vietnam, due to the huge cost disadvantage of patented drugs, their lower-cost bioequivalent generics are recommended as replacements as stated in the Health Ministry's drugs policy [3-4]. In fact, the proportion of the budget to purchase patented drugs, which is regulated by the Health Ministry, depends on the hospital levels [5]. As of June 2018, lists of off-patent and off-exclusivity drugs and their approved generics have not been announced by the Vietnam Ministry of Health. Consequently, these off-patent and off-exclusivity drugs still won the high bid prices which had a great impact on the drugs budget of hospitals and the affordability for drugs of communities. Additionally, according to regulations on drug registration, each patented drug obtains a registration number for circulation which expires every 5 y [6]. Therefore, the lists of patented drugs in hospitals vary regarding both types and quantity every year.

Nguyen-Dinh-Chieu Hospital, which has 1,100 beds, is the largest general hospital in Ben-Tre Province and all medical examination and treatment costs are reimbursed by Health Insurance Funding. As of 2018, the hospital is officially recognized as one of the first level hospitals in Vietnam. The study was conducted to discover main characteristics of patented drugs utilization at Nguyen-Dinh-Chieu Hospital during the $7 \mathrm{y}$ period.

\section{MATERIALS AND METHODS}

\section{Study design}

The cross-sectional descriptive study was carried out on the retrospective data of all patented drugs used at Nguyen-Dinh-Chieu Hospital in Ben-Tre Province from 2011 to 2017. Criteria for selecting the subjects were as follows: be in the drugs list of the hospital from 2011 to 2017, and be in the 18 lists issued by the Health Ministry about patented drugs used in hospitals from 2013 to 2017.

\section{Descriptive criteria}

The characteristics of drugs utilization were described by frequency and percentage of drugs quantities and costs. Criteria for the description were as follows: active ingredient, route of administration, therapeutic class (classified according to the circular No. 40/2014/TTBYT) and manufacturing country. The characteristics related to the registration for circulation of patented drugs in Vietnam were also introduced in this study.

\section{RESULTS}

\section{The general characteristics of patented drugs utilized}

During the 7-year period, Nguyen-Dinh-Chieu Hospital utilized a total of 212 patented drugs, relating to 145 different active ingredients. Single ingredient drugs accounted for $88.0 \%$ of the total number of patented drugs and $87.5 \%$ of the total spending on patented drugs. The proportion of the spending on injectable drugs was twice as high as the proportion for oral drugs (59.5\% vs $28.1 \%$ ). Patented drugs were classified in 20 therapeutic classes, in which antimicrobial and cardiovascular drugs represented the highest proportions both in the number of drugs and the spending on drugs. $79 \%$ of patented drugs were manufactured by pharmaceutical companies in Europe and the majority came from Germany (39 drugs) and France (38 drugs). $70.3 \%$ of patented drugs had been registered for the first time during the period of study (fig. 1).

\section{The patented drugs utilization}

The spending on patented drugs increased by 18\% from 2011 to 2015 fig. 2. Regarding routes of administration, the ratios of patented drugs used were stable. Regarding therapeutic classes and manufacturing companies, those ratios fluctuated during the 2011-2017 period. table 1 


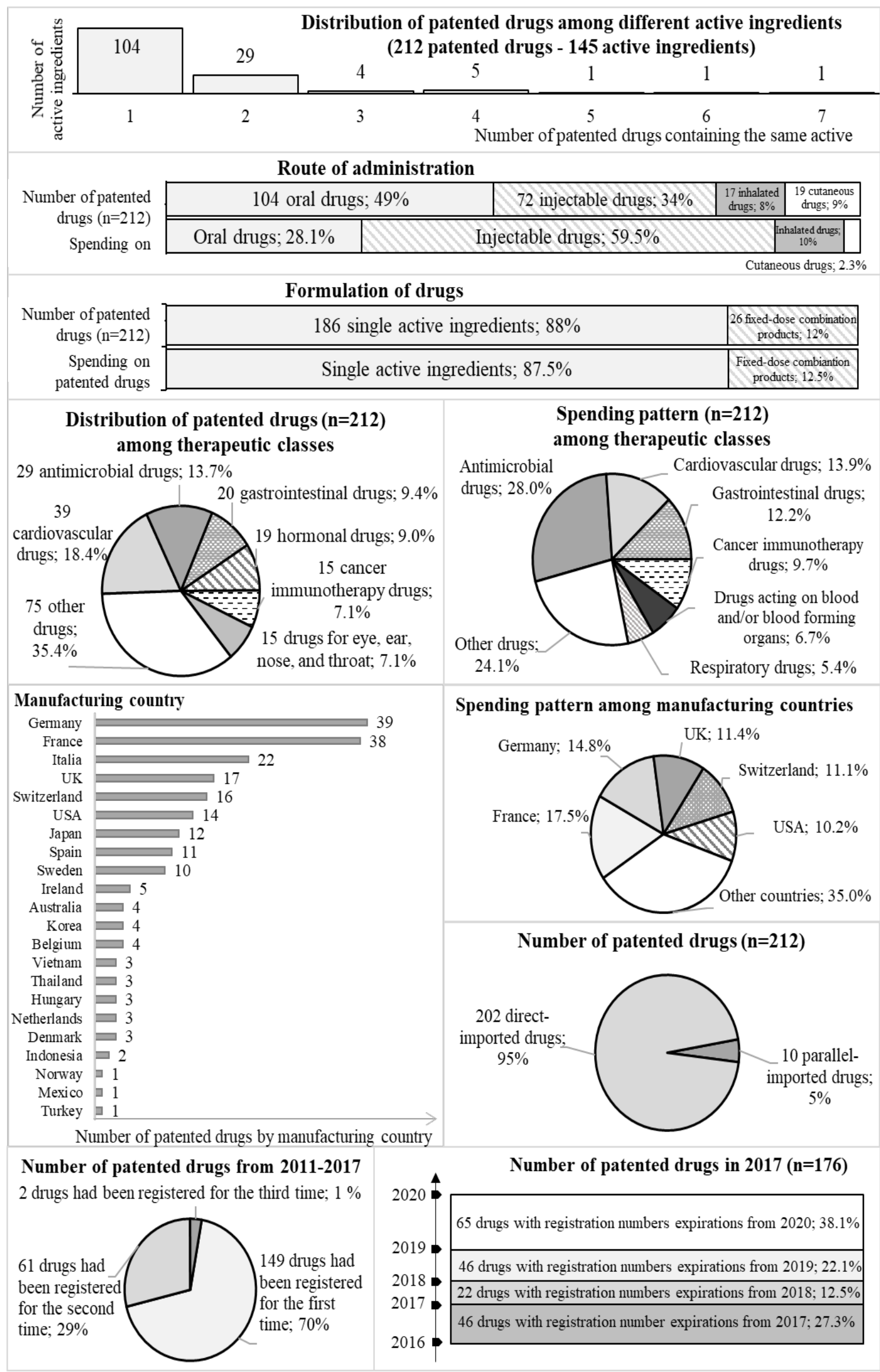

Fig. 1: The general characteristics of patented drugs utilized at NDCBT in the period of 2011-2017 
Table 1: Description of characteristics of patented drugs utilized at NDCBT in the period of 2011-2017

\begin{tabular}{|c|c|c|c|c|c|c|c|c|c|c|c|c|c|c|c|c|}
\hline \multirow[t]{4}{*}{ Year } & \multicolumn{8}{|c|}{ Number of patented drugs } & \multicolumn{8}{|c|}{ Ratio of spending on patented drugs } \\
\hline & 2011 & 2012 & 2013 & 2014 & 2015 & 2016 & 2017 & $\begin{array}{l}\text { 2011- } \\
2017 \\
\end{array}$ & 2011 & 2012 & 2013 & 2014 & 2015 & 2016 & 2017 & $\begin{array}{l}2011- \\
2017 \\
\end{array}$ \\
\hline & $\mathbf{n}=$ & $\mathbf{n}=$ & $\mathrm{n}=$ & $\mathbf{n}=$ & $\mathbf{n}=$ & $\mathrm{n}=156$ & $\mathbf{n}=$ & $\mathrm{n}=\mathbf{2 1 2}$ & (\%) & (\%) & $(\%)$ & (\%) & (\%) & (\%) & (\%) & (\%) \\
\hline & $\begin{array}{l}53 \\
(\%)\end{array}$ & $\begin{array}{l}77 \\
(\%)\end{array}$ & $\begin{array}{l}94 \\
(\%)\end{array}$ & $\begin{array}{l}104 \\
(\%)\end{array}$ & $\begin{array}{l}114 \\
(\%)\end{array}$ & (\%) & $\begin{array}{l}176 \\
(\%)\end{array}$ & (\%) & & & & & & & & \\
\hline \multicolumn{17}{|c|}{ Manufacturing country } \\
\hline Germany & $\begin{array}{l}8 \\
(15.1)\end{array}$ & $\begin{array}{l}9 \\
(11.7)\end{array}$ & $\begin{array}{l}11 \\
(11.7)\end{array}$ & $\begin{array}{l}14 \\
(13.5)\end{array}$ & $\begin{array}{l}20 \\
(17.5)\end{array}$ & $\begin{array}{l}28 \\
(17.9)\end{array}$ & $\begin{array}{l}33 \\
(18.8)\end{array}$ & $\begin{array}{l}39 \\
(18.4)\end{array}$ & 35.4 & 28.7 & 23.2 & 20.0 & 13.5 & 16.1 & 12.4 & 17.5 \\
\hline France & $\begin{array}{l}14 \\
(26.4)\end{array}$ & $\begin{array}{l}21 \\
(27.3)\end{array}$ & $\begin{array}{l}22 \\
(23.4)\end{array}$ & $\begin{array}{l}21 \\
(20.2)\end{array}$ & $\begin{array}{l}20 \\
(17.5)\end{array}$ & $\begin{array}{l}28 \\
(17.9)\end{array}$ & $\begin{array}{l}29 \\
(16.5)\end{array}$ & $\begin{array}{l}38 \\
(17.9)\end{array}$ & 20.0 & 18.8 & 11.8 & 8.4 & 11.7 & 12.5 & 21.2 & 14.8 \\
\hline UK & $\begin{array}{l}6 \\
(11.3)\end{array}$ & $\begin{array}{l}6 \\
(7.8)\end{array}$ & $\begin{array}{l}14 \\
(14.9)\end{array}$ & $\begin{array}{l}12 \\
(11.5)\end{array}$ & $\begin{array}{l}14 \\
(12.3)\end{array}$ & $\begin{array}{l}13 \\
(8.3)\end{array}$ & $\begin{array}{l}12 \\
(6.8)\end{array}$ & $\begin{array}{l}17 \\
(8.0)\end{array}$ & 4.3 & 2.8 & 11.0 & 16.6 & 18.5 & 10.3 & 8.2 & 11.4 \\
\hline Switzerland & $\begin{array}{l}4 \\
(7.5)\end{array}$ & $\begin{array}{l}6 \\
(7.8)\end{array}$ & $\begin{array}{l}6 \\
(6.4)\end{array}$ & $\begin{array}{l}7 \\
(6.7)\end{array}$ & $\begin{array}{l}8 \\
(7.0)\end{array}$ & $\begin{array}{l}16 \\
(10.3)\end{array}$ & $\begin{array}{l}15 \\
(8.5)\end{array}$ & $\begin{array}{l}16 \\
(7.5)\end{array}$ & 3.6 & 11.8 & 12.6 & 14.5 & 10.5 & 11.8 & 10.0 & 11.1 \\
\hline Other & $\begin{array}{l}21 \\
(39.6)\end{array}$ & $\begin{array}{l}35 \\
(45.5)\end{array}$ & $\begin{array}{l}41 \\
(43.6)\end{array}$ & $\begin{array}{l}50 \\
(48.1)\end{array}$ & $\begin{array}{l}52 \\
(45.6)\end{array}$ & $\begin{array}{l}71 \\
(45.5)\end{array}$ & $\begin{array}{l}123 \\
(49.4)\end{array}$ & $\begin{array}{l}102 \\
(48.1)\end{array}$ & 36.7 & 37.9 & 41.4 & 40.5 & 45.8 & 49.3 & 48.2 & 45.2 \\
\hline \multicolumn{17}{|c|}{ Route of administration } \\
\hline Oral drugs & $\begin{array}{l}28 \\
(52.8)\end{array}$ & $\begin{array}{l}40 \\
(51.9)\end{array}$ & $\begin{array}{l}48 \\
(51.1)\end{array}$ & $\begin{array}{l}50 \\
(48.1)\end{array}$ & $\begin{array}{l}53 \\
(46.5)\end{array}$ & $\begin{array}{l}75 \\
(48.1)\end{array}$ & $\begin{array}{l}90 \\
(51.1)\end{array}$ & $\begin{array}{l}104 \\
(49.0)\end{array}$ & 34.8 & 30.1 & 33.4 & 21.8 & 24.3 & 27.5 & 31.2 & 28.1 \\
\hline Injectable drugs & $\begin{array}{l}18 \\
(34.0)\end{array}$ & $\begin{array}{l}28 \\
(36.4)\end{array}$ & $\begin{array}{l}33 \\
(35.1)\end{array}$ & $\begin{array}{l}34 \\
(32.7)\end{array}$ & $\begin{array}{l}39 \\
(34.2)\end{array}$ & $\begin{array}{l}50 \\
(32.1)\end{array}$ & $\begin{array}{l}56 \\
(31.8)\end{array}$ & $\begin{array}{l}72 \\
(34.0)\end{array}$ & 56.8 & 60.9 & 53.7 & 66.2 & 64.2 & 58.7 & 55.7 & 59.5 \\
\hline Inhalated drugs & $\begin{array}{l}4 \\
(7.5)\end{array}$ & $\begin{array}{l}5 \\
(6.5)\end{array}$ & $\begin{array}{l}9 \\
(9.6)\end{array}$ & $\begin{array}{l}13 \\
(12.5)\end{array}$ & $\begin{array}{l}14 \\
(12.3)\end{array}$ & $\begin{array}{l}14 \\
(9.0)\end{array}$ & $\begin{array}{l}14 \\
(8.0)\end{array}$ & $\begin{array}{l}17 \\
(8.0)\end{array}$ & 6.1 & 7.7 & 12.0 & 11.1 & 10.1 & 10.5 & 9.6 & 10.0 \\
\hline $\begin{array}{l}\text { Cutaneous } \\
\text { drugs } \\
\text { Therapeutic class }\end{array}$ & $\begin{array}{l}3 \\
(5.7)\end{array}$ & $\begin{array}{l}4 \\
(5.2)\end{array}$ & $\begin{array}{l}4 \\
(4.3)\end{array}$ & $\begin{array}{l}7 \\
(6.7)\end{array}$ & $\begin{array}{l}8 \\
(7.0)\end{array}$ & $\begin{array}{l}17 \\
(10.9)\end{array}$ & $\begin{array}{l}16 \\
(9.1)\end{array}$ & $\begin{array}{l}19 \\
(9.0)\end{array}$ & 2.3 & 1.3 & 0.9 & 0.8 & 1.4 & 3.3 & 3.5 & 2.3 \\
\hline $\begin{array}{l}\text { Cardiovascular } \\
\text { drugs }\end{array}$ & $\begin{array}{l}13 \\
(24.5)\end{array}$ & $\begin{array}{l}22 \\
(28.6)\end{array}$ & $\begin{array}{l}27 \\
(28.7)\end{array}$ & $\begin{array}{l}22 \\
(21.2)\end{array}$ & $\begin{array}{l}19 \\
(16.7)\end{array}$ & $\begin{array}{l}24 \\
(15.4)\end{array}$ & $\begin{array}{l}29 \\
(16.5)\end{array}$ & $\begin{array}{l}39 \\
(18.4)\end{array}$ & 27.4 & 21.9 & 24.2 & 15.3 & 10.5 & 11.1 & 10.3 & 13.9 \\
\hline $\begin{array}{l}\text { Antimicrobial } \\
\text { drugs }\end{array}$ & $\begin{array}{l}13 \\
(24.5)\end{array}$ & $\begin{array}{l}14 \\
(18.2)\end{array}$ & $\begin{array}{l}18 \\
(19.1)\end{array}$ & $\begin{array}{l}20 \\
(19.2)\end{array}$ & $\begin{array}{l}22 \\
(19.3)\end{array}$ & $\begin{array}{l}25 \\
(16.0)\end{array}$ & $\begin{array}{l}26 \\
(14.8)\end{array}$ & $\begin{array}{l}29 \\
(13.7)\end{array}$ & 43.0 & 29.0 & 24.3 & 37.3 & 34.1 & 26.0 & 19.1 & 28.0 \\
\hline $\begin{array}{l}\text { Gastrointestinal } \\
\text { drugs }\end{array}$ & $\begin{array}{l}4 \\
(7.5)\end{array}$ & $\begin{array}{l}5 \\
(6.5)\end{array}$ & $\begin{array}{l}7 \\
(7.4)\end{array}$ & $\begin{array}{l}10 \\
(9.6)\end{array}$ & $\begin{array}{l}11 \\
(9.6)\end{array}$ & $\begin{array}{l}15 \\
(9.6)\end{array}$ & $\begin{array}{l}19 \\
(10.8)\end{array}$ & $\begin{array}{l}20 \\
(9.4)\end{array}$ & 2.8 & 3.4 & 8.0 & 13.6 & 12.7 & 16.1 & 13.0 & 12.2 \\
\hline $\begin{array}{l}\text { Cancer } \\
\text { immunotherapy } \\
\text { drugs }\end{array}$ & $\begin{array}{l}1 \\
(1.9)\end{array}$ & $\begin{array}{l}5 \\
(6.5)\end{array}$ & $\begin{array}{l}6 \\
(6.4)\end{array}$ & $\begin{array}{l}4 \\
(3.8)\end{array}$ & $\begin{array}{l}7 \\
(6.1)\end{array}$ & $\begin{array}{l}10 \\
(6.4)\end{array}$ & $\begin{array}{l}12 \\
(6.8)\end{array}$ & $\begin{array}{l}15 \\
(7.1)\end{array}$ & 1.4 & 7.3 & 8.7 & 1.0 & 10.2 & 7.9 & 17.7 & 9.7 \\
\hline Other drugs & $\begin{array}{l}22 \\
(41.5) \\
\end{array}$ & $\begin{array}{l}31 \\
(40.2) \\
\end{array}$ & $\begin{array}{l}36 \\
(38.3) \\
\end{array}$ & $\begin{array}{l}48 \\
(46.2) \\
\end{array}$ & $\begin{array}{l}55 \\
(48.2) \\
\end{array}$ & $\begin{array}{l}82 \\
(52.6) \\
\end{array}$ & $\begin{array}{l}90 \\
(51.1) \\
\end{array}$ & $\begin{array}{l}109 \\
(51.4)\end{array}$ & 25.4 & 38.4 & 34.8 & 32.8 & 32.5 & 38.9 & 39.9 & 36.2 \\
\hline
\end{tabular}

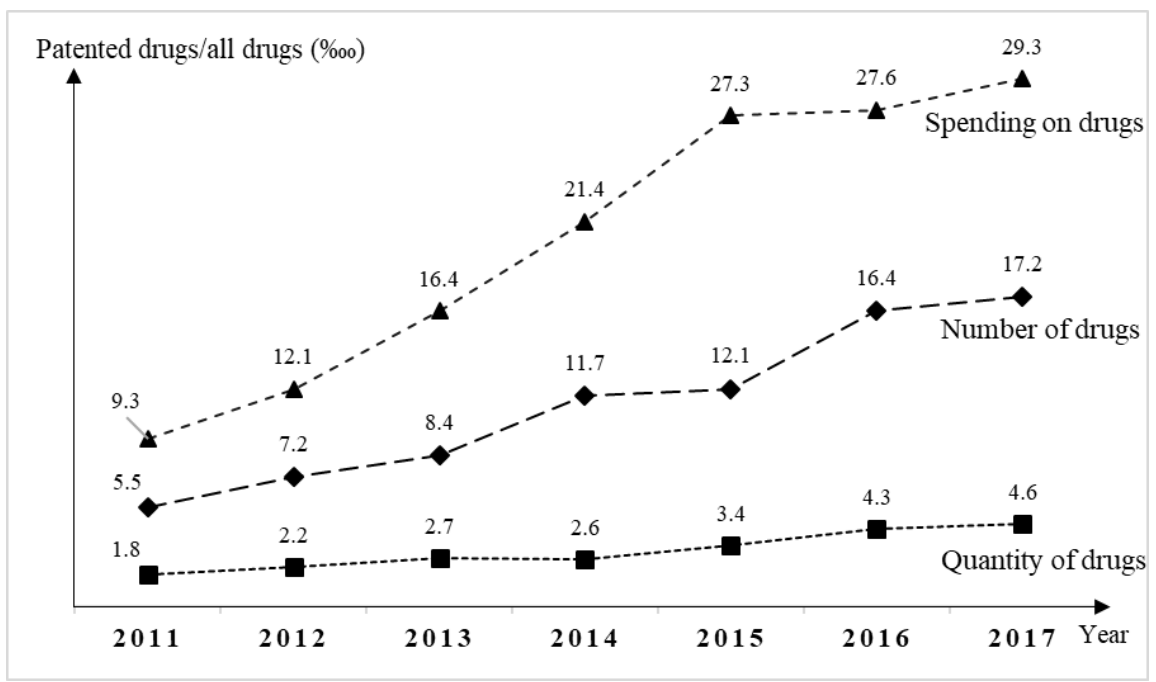

Fig. 2: The trends in the utilization of 212 patented drugs compared to all drugs at NDCBT in the period of 2011-2017

\section{DISCUSSION}

The study described the main characteristics of the utilization of 212 patented drugs used at Nguyen-Dinh-Chieu Hospital in the period of 2011-2017. Compared to the characteristics of disease patterns in the hospital during the same period, the study discovered a difference between the most common type of patented drugs utilized and the most common reasons for inpatient visits (which are respiratory diseases with the incidence of $14.0 \%$ ] [7]. These results suggest that there might be a correlation between the prescription of patented drugs and the medical conditions of patients. Particularly, patented drugs might be prioritized to use if patients were in the first stage of a treatment therapy or patients were in severe clinal conditions. In cases that patients' clinical conditions were improving, physicians might consider switching to lower-cost and bioequivalent generic alternatives. The utilization of patented drugs was illustrated according to the number of drug types and the annual spending with fluctuations recognized after comparing with different therapeutic classes or different manufacturing countries. These characteristics were consistent with other characteristics recorded from previous studies [8-9]. In 2017, the spending on patented drugs at Nguyen-Dinh-Chieu Hospital accounted for 29.3\% of the total spending on drugs. This proportion was higher than the recommended proportion of spending on patented drugs for the first level hospital according to the agreement between the Health Ministry and the Vietnam Social Security [5]. Consequently, it is necessary to take measures to reduce the spending on patented drugs at the hospital in the next period. 
This is the first study that investigated the characteristics of patented drugs utilization at a certain hospital over a long period of time. With full and diverse data, the patented drugs utilization at Nguyen-Dinh-Chieu Hospital was described according to many criteria, from which many important pieces of information were revealed. This study is the foundation for future studies to develop a full picture of patented drugs utilization.

\section{LIMITATIONS}

A patented drug was defined in this study based on the patented drug definition specified in the Circular No. 11/2016/TT-BYT of the Vietnamese Ministry of Health [10]. This definition was not completely consistent with the definition in the pharmaceutical manufacture field, thus, there were limitations in comparing and discussing the results of this study with literature.

\section{CONCLUSION}

The study showed trends in utilizing patented drugs year by year at Nguyen-Dinh-Chieu Hospital. It is the reference study which other hospitals will be able to apply to optimize the structure of the drugs list, from which the balance of therapeutic efficacy and affordability for drugs of local communities will be obtained.

\section{ACKNOWLEDGEMENT}

The authors thank the management of the Nguyen-Dinh-Chieu Hospital and heads of respective departments for permission and support to conduct the study.

\section{AUTHORS CONTRIBUTIONS}

HTNV designed the study, evaluated the overall research results and revised manuscript. CTT prepared the overview, analyzed data, performed data interpretation and drafting of the manuscript. TTNV performed data interpretation and drafting of the manuscript. DKL revised manuscript. All authors have read and approved the final manuscript.

\section{CONFLICTS OF INTERESTS}

All authors have none to declare

\section{REFERENCES}

1. Nhac-Vu HT, Ngoc-Van TT, Kim-Tuyen NT. Drecribing the list of drugs of district 7 hospital in 2014. J Practical Med 2016;61:21-3.

2. Nhu H, Thanh Tuyen $\mathrm{C}$, Nhac Vu HT. Characteristics of the modern medicines list used at phu nhuan hospital in 20122017. Y Hoc TP. Ho Chi Minh 2017;5:135-41.

3. Vietnam Ministry of Health. Circular No. 21/2013/TT-BYT Prescribing organization and operation of the Drug And Treatment Council in hospitals. Ha Noi; 2013.

4. Vietnam Ministry of Health. Circular No. 40/2014/TT-BYT Promulgation and guidelines for list of modern medicines covered by health insurance. Ha Noi; 2014.

5. Vietnam Social Security. Official Dispatch No. 3968/BHXH-DVT agreement on the ratios of drugs spending on patented drugs at health facilities in accordance to the Government. Ha Noi; 2017.

6. Vietnam Ministry of Health. Circular No. 44/2014/TT-BYT on registration of drugs. Ha Noi; 2014.

7. Nhac Vu HT, Thanh Thuy N, Kim Loan D, Trong Nhan VP. Characteristics of the disease patterns at Nguyen Dinh Chieu hospital in 2011-2017. Y hoc Tp. Ho Chi Minh 2018;22(Suppl 1):285-92.

8. Devi Thadiboina M, Bala Adithya S, Vadivel K. Drug utilisation review in postoperative patients in obstetrics-gynaecology and surgical gastroenterology departments-a retrospective study. Int J Pharm Pharm Sci 2018;10:11-5.

9. Atal S, Deshmankar B, Nawaz SA. Cost analysis of commonly used drugs under price control in India: assessing the effect of drug price control order on brand price variation. Int J Pharm Pharm Sci 2016;8:315-21.

10. Vietnam Ministry of Health. Circular No. 11/2016/TT-BYT Bidding for supply of drugs for public health facilities. Ha Noi; 2016. 